\title{
Body Mass Index (BMI) of children with Tetralogy of Fallot (TOF)
}

\author{
Ovin Nada Saputri ${ }^{1}$, Viskasari P. Kalanjati ${ }^{2 *}$, Mahrus A. Rahman ${ }^{3 *}$
}

${ }^{1}$ Medical Program, Faculty of Medicine, Universitas Airlangga, Surabaya, Indonesia, ${ }^{2}$ Department of Anatomy, Histology and Pharmacology, Faculty of Medicine, Universitas Airlangga, Surabaya, Indonesia, ${ }^{3}$ Department of Pediatrics, Dr. Soetomo General Academic Hospital, Surabaya, Indonesia

\begin{tabular}{|c|c|}
\hline Article Info & ABSTRACT \\
\hline $\begin{array}{l}\text { Article history: } \\
\text { Received Oct, } 152019 \\
\text { Revised Dec 1, } 2019 \\
\text { Accepted Dec 9, } 2019 \\
\text { Published Jan 1, } 2020\end{array}$ & $\begin{array}{l}\text { Background: Malnutrition is a common cause of morbidity and } \\
\text { mortality amongst children with TOF. Objective: To analyze the } \\
\text { BMI profile of children with TOF aged } 0-18 \text { years at Pediatric } \\
\text { Department, Dr. Soetomo General Academic Hospital, Surabaya, } \\
\text { Indonesia. Materials and Methods: A cross-sectional study of the } \\
\text { BMI from the medical record of TOF patients aged } 0-18 \text { years at } \\
\text { the Pediatric Department, Dr. Soetomo General Academic Hospital, }\end{array}$ \\
\hline $\begin{array}{l}\text { Keywords: } \\
\text { Tetralogy of Fallot } \\
\text { Children } \\
\text { Characteristic } \\
\text { Body Mass Index } \\
\text { Underweight } \\
\text { Child well-being index } \\
\text { Cardiovascular disease }\end{array}$ & $\begin{array}{l}\text { Surabaya, Indonesia, since January } 2016 \text { to December } 2017 \text { was } \\
\text { conducted. The data included gender, age group, demographic } \\
\text { distribution, weight, and height. BMI was calculated by WHO } \\
\text { formula reference; body weight (kg) divided by body height squared } \\
\left(\mathrm{m}^{2}\right) \text {, which was converted into z-score histogram. BMI } \\
\text { classification was guided by the Government's Anthropometry } \\
\text { Standards for Nutritional Status Assessment. Result: From } 84 \text { TOF } \\
\text { patients, there were } 43 \text { males }(51 \%) \text { and } 41 \text { females }(49 \%) \text {. The most } \\
\text { dominant age group was } 0-4 \text { years old }(n=47 ; 56 \%) \text {. The majority } \\
\text { of patients were from outside of Surabaya }(n=64 ; 76.2 \%) \text {. Based on } \\
\text { their BMI, } 36 \text { patients }(42.9 \%) \text { had severe underweight, } 10 \text { patients } \\
(11.9 \%) \text { were underweight, and } 35 \text { patients }(41.7 \%) \text { were normal, } \\
\text { whilst the rests }(3.6 \%) \text { were overweight. Conclusion: The number } \\
\text { of male patients was slightly higher than female patients. The } \\
\text { majority of TOF patients were } 0-4 \text { years old and resided out town } \\
\text { of Surabaya. The predominant BMI found was the underweight and } \\
\text { severe underweight below normal BMI. }\end{array}$ \\
\hline
\end{tabular}

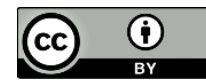

\section{Corresponding Author:}

Viskasari P. Kalanjati

Department of Anatomy, Histology and Pharmacology, Faculty of Medicine, Universitas Airlangga Jl. Mayjen. Prof. Moestopo no. 47, Surabaya 60131, East Java, Indonesia viskasari-p-k@fk.unair.ac.id

\section{BACKGROUND}

Tetralogy of Fallot (TOF) is a type of cyanosis CHD characterized by 4 abnormal structures of the heart, that are ventricular septal defect (VSD), pulmonary artery obstruction, right ventricular hypertrophy, and aortic overriding (Ontoseno, 2014). These abnormalities can disrupt the patient's hemodynamics which results in stunted growth and development in TOF patients. Malnutrition is often found in patients with congenital heart disease (CHD). A study reported that $90.4 \%$ of congenital heart disease patients in Nigeria are malnourished. Sixty percent of patients with cyanosis CHD have a malnutrition condition. The condition is associated with anemia, congestive heart failure, poor fat diets, and surgical delays in TOF patients (Okoromah, et al., 2011). Poor growth with underweight for age, 
decrease length/height for age, and underweigh-for-height are common in CHD pediatric patients, especially in low- and middle-income countries. It has multifactorial underlying causes, including innate growth potential, severity of cardiac disease, increased energy requirements, decreased nutritional intake, malabsorbtion, and poor utilization of absorbed nutrition (Argent, et al., 2017). In Indonesia, 59\% of patients with congenital heart disease in the intensive care unit (ICU) of the pediatric heart disease at a type A hospital reported experiencing malnutrition. Malnutrition in TOF patients affects the quality of post-surgical life. This is indicated by the extended treatment time using a mechanical ventilation machine, thereby extending the ICU stay (Marwali, et al., 2015). BMI is one of the indicators of nutrition based on a person's weight and height according to gender and age group (Ministry of Health Republic of Indonesia, 2013). Although it is still debated, data on BMI in children with TOF has not been widely reported in Indonesia (Wulandari, et al., 2018).

\section{OBJECTIVE}

This study was conducted to analyze the profile of BMI in TOF patients in children aged 0-18 years old treated at the Department of Pediatrics, Dr. Soetomo General Academic Hospital, Surabaya, Indonesia, during 2016-2017.

\section{MATERIALS AND METHODS}

This study was a cross-sectional observational study using medical record data of TOF patients aged 0-18 years old treated at the Department of Pediatrics, Dr. Soetomo General Academic Hospital, Surabaya, Indonesia, from January 2016 to December 2017. The patients with incomplete/no data were excluded. The variables of this study included gender, age group, demographic distribution, weight, and height. Weight and height data were taken when the patient was firstly admitted to the hospital. BMI calculation was carried out according to WHO formula reference; that is body weight ( $\mathrm{kg}$ ) divided by body height squared $\left(\mathrm{m}^{2}\right)$. Data from this study were analyzed by using descriptive statistics including percentile analysis and BMI z-score histograms which were then classified into 4 groups according to the Decree of the Minister of Health of Republic of Indonesia Number 1995 of 2010 concerning Anthropometric Standards for Assessment of Children's Nutrition Status. Classification of BMI in children is the classification based on age at 0-60 months; group $1=$ severe underweight with a threshold $<-3 \mathrm{SD}$, group $2=$ underweight with a threshold of $-3 \mathrm{SD}$ up to $<-2 \mathrm{SD}$, group $3=$ normal with a threshold of -2 SD up to 2 SD, and group $4=$ overweight with a threshold $>2$ SD (Ministry of Health Republic of Indonesia, 2011).

\section{RESULTS}

During the observed period there were 118 pediatric patients diagnosed with TOF, but in the process, 34 files were excluded. Therefore, the sample of data used in this study was 84 patients. From the 84 TOF pediatric patients, there were 43 male patients (51\%) and 41 female patients (49\%). Detailed descriptive statistical data can be seen in Table 1 and 2.

Table 1. Data on gender, age group, and address of pediatric TOF patients in the Department of Pediatrics, Dr. Soetomo General Academic Hospital, Surabaya, Indonesia, in 2016 2017.

\begin{tabular}{lcccc}
\hline & & Male $(\mathrm{n})$ & Female $(\mathrm{n})$ & Total $(\mathrm{n})$ \\
\hline Age groups & $0-4$ & 27 & 20 & 47 \\
& $5-10$ & 7 & 15 & 22 \\
& $11-18$ & 9 & 6 & 15 \\
\hline Address & Surabaya & 9 & 11 & 20 \\
& Outside of & 34 & 30 & 64 \\
& Surabaya & & & \\
\hline BMI & Severe & & 22 & 36 \\
Category & Underweight & 14 & 3 & 10 \\
& Underweight & 7 & 16 & 35 \\
& Normal & 19 & 0 & 3 \\
\hline
\end{tabular}


Table 2. Comparison of BMI statistical data for pediatric TOF patients in the Department of Pediatrics, Dr. Soetomo General Academic Hospital, Surabaya, Indonesia in 2016 2017.

\begin{tabular}{llll}
\hline & Male & Female & $\begin{array}{l}\text { Combined } \\
\text { Sex }\end{array}$ \\
\hline $\mathrm{N}$ & 43 & 41 & 84 \\
Mean & 16.388 & 13.811 & 15.130 \\
Std. Error of Mean & 1.0937 & 0.4069 & 0.6073 \\
Std. Deviation & 7.1716 & 2.6056 & 5.5656 \\
Variance & 51.432 & 6.789 & 30.976 \\
Skewness & 3.005 & 0.052 & 3.686 \\
Std. Error of Skewness & 0.361 & 0.369 & 0.263 \\
Range & 40.0 & 12.5 & 40.5 \\
Minimum & 8.0 & 7.5 & 7.5 \\
Maximum & 48.0 & 20.0 & 48.0 \\
Percentiles & & & \\
$\quad-\quad 5$ & 10.524 & 8.368 & 9.974 \\
$\quad-\quad 25$ & 12.927 & $12, .308$ & 12.627 \\
$\quad-\quad 50$ & 14.746 & 13.350 & 13.888 \\
$-\quad 75$ & 17.244 & 16.008 & 16.029 \\
\hline \multicolumn{1}{c}{95} & 36.208 & 18.725 & 21.957 \\
\hline
\end{tabular}

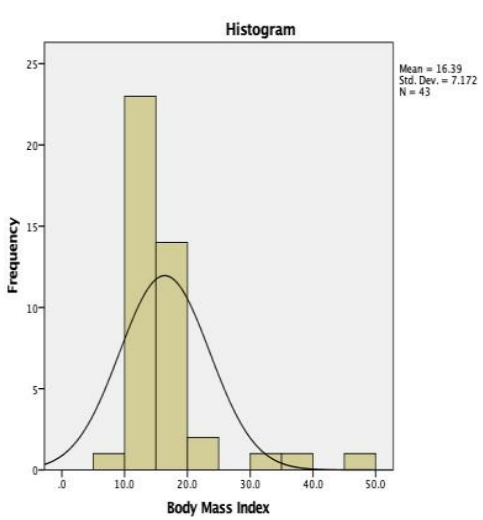

(a)

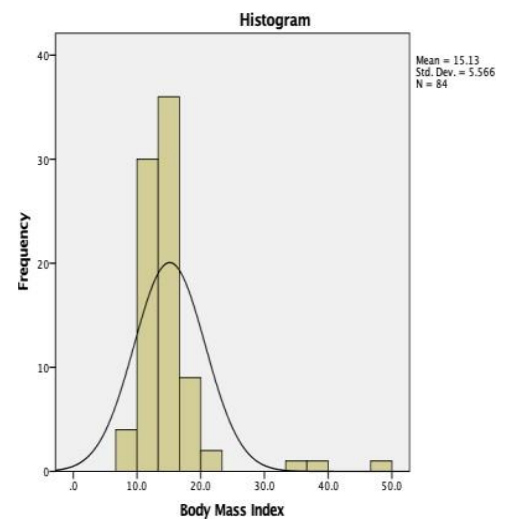

(b)

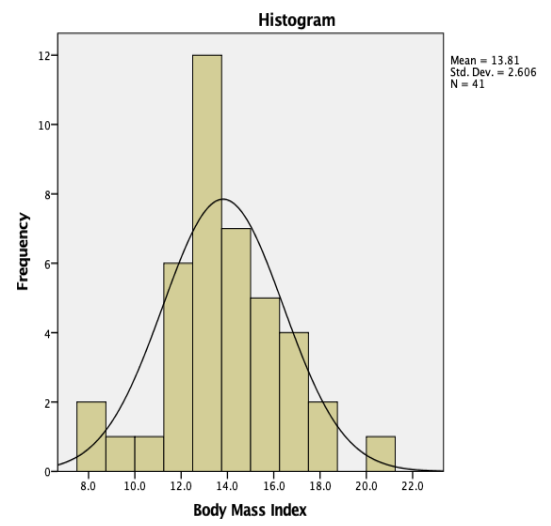

(c)

Figure 1. BMI distribution in TOF pediatric patients with male (a), female (b), and combined sex (c).

Based on the result of the study, most dominant patients found in TOF pediatric are in the age group of 0-4 years old, as many as 47 patients (56\%). In the age group of 5-10 years old, there were 22 patients $(26.2 \%)$ and in the age group of 11-18 years old, there were 15 patients (17.9\%). From the study, 64 patients $(76.2 \%)$ were from outside of Surabaya and 20 patients $(23.8 \%)$ were from Surabaya. In this study, TOF patients included in the severely underweight category were 36 patients $(42.9 \%)$, the underweight category was 10 patients (11.9\%), the normal category was 35 patients (41.7\%), and in the overweight category, there were 3 patients (3.6\%) (Table 1-2).

\section{DISCUSSION}

From the result of the study, it was found that the number of male patients was slightly higher than female patients. Based on a year of care, TOF pediatric patients who were admitted to the hospital in 2016 were mostly female, while in 2017 , the majority was male. Gender is one of the risk factors that is still being debated regarding the correlation with the occurrence of TOF in children. In a recent study, it was found that TOF can affect males and females equally (Friaz \& Guillaume, 2020). The study by Valente, et al. (2019) based on data from the Center for Congenital Heart in America, Canada and Europe had another result. Based on the result of the study, the number of TOF patients for boys was higher than TOF patients for girls (Valente, et al., 2019). 
In this study, the majority of TOF patients who come to the hospital were in the age group of 0-4 years old. The best age for elective definitive surgical correction in TOF pediatric patients is between 3 and 6 months of age in asymptomatic and mildly symptomatic children. Children with severe symptom of TOF should get surgical correction immediately without considering their age (Martins, et al., 2018). This is not much different from research conducted by Arsdell, et al. (2018), where the optimal age for elective repair of TOF is 3 to 11 months of age. This study was based on mortality and physiological outcomes data of time to lactate clearance, ventilation hours, and length of stay, but not death. The mortality of TOF pediatric patients occurred with primary repair at an age more than 12 months (Arsdell, et al., 2018). The opposite result was obtained by Tchoumi, et al. (2011) that TOF patients over a year old had a very good surgical result. However, the right ventricular function and pulmonary valve will need close surveillance, and timely and appropriate interventions must be taken to optimise outcomes (Tchoumi, et al., 2011).

From the analysis of medical record data, most of the TOF pediatric patients came from outside of Surabaya. This might be due to Dr. Soetomo General Academic Hospital is a referral hospital center for eastern Indonesia. Besides, by using of Universal Health Coverage in Indonesia, it makes people get easy to choose the best health facilities. In 2014, the Social Insurance Administration Organization (BPJS) was officially employed as a national health insurance guarantee. The cost of handling a TOF case can be borne by BPJS which includes types of operative and non-operative actions (BPJS Health Insurance, 2018).

Most of the TOF pediatric patients in this study were categorized as 'underweight' and 'severely underweight' based on the BMI classification from the Decree of the Minister of Health of Republic of Indonesia Number 1995 of 2010 concerning Anthropometric Standards for Assessment of Children's Nutrition Status (Ministry of Health, Republic of Indonesia, 2011). This is similar to the result of research conducted by Schwartz et al (2017), it was reported that pediatric patients ( $1-15$ years) with congenital heart disease (CHD) have an underweight prevalence which is higher compared to the general population. Underweight condition in patients with CHD can indicate the decrease of intake nutrition in patients due to impaired cardiovascular function and respiration; besides the relative hypoperfusion due to cyanosis. This affects the average growth and development rate of TOF children so that it falls below the average of the control group in the same age period. Other factors that can disrupt of growth and development in children with TOF is a fairly long period of CHD management both in conservative and operative therapy; the time of surgery for total correction and BT-shunt therapy as well as other tertiary diagnostic therapies that determine a child's stay with TOF can cause nutritional disorders due to chronic physical and psychological stress (Daymont, et al., 2013). In an Egyptian study, it was reported that $84 \%$ of patients with poor nutritional status were found in patients with congenital heart defects including TOF; where poor nutritional status or malnutrition is the most frequent complication. TOF causes the patient's hemodynamic condition to be disrupted and causes complications and accompanying pathology including anemia, decreased $\mathrm{SaO} 2$, heart failure, and pulmonary hypertension which often causes a decrease in the nutritional status of children with TOF (Hassan, et al., 2015). Correction of anemia pre-operative has been reported to reduce morbidity and mortality in children with TOF, one of which is through iron supplementation therapy (Ontoseno and Soebijanto, 2014). Patients with CHD with malnutrition should maintain adequate nutritional status. However, most of TOF pediatric patients are not able to ingest enough calories. Therefore, it is advisable to provide enteral nutrition directly (Yasmin \& Gunawijaya, 2015).

\section{CONCLUSION}

From this study, it was found that male patients were slightly more numerous than female patients. Most TOF cases are at the age of 0-4 years old. The majority of patients come from outside of Surabaya. Most pediatric patients with TOF are found in the category below the normal BMI standard.

\section{REFERENCES}

Argent, A.C., Balachandran, R., Vaidyanathan, B., Khan, A., Kumar, R.K., 2017. Management of undernutrition and failure to thrive in children with congenital heart disease in low- and middleincome countries. Cardiology in the Young. 27(Suppl. 6): S22-S30. 
BPJS Health [BPJS Kesehatan, 2018]. Sejarah perjalanan jaminan sosial di Indonesia [History of social security in Indonesia]. Downloaded 5 June 2019 from https://bpjs-kesehatan.go.id.

Daymont, C., Neal, A., Prosnitz, A., Cohen, M., 2013. Growth in children with congenital heart disease. Pediatrics, 131(1): e236- e242.

Hassan, B., Albanna, E., Morsy, S., Siam, A., Shafie, M., Elsaadany, H., Sherbiny, H., Shehab, M., Grollmuss, O., 2015. Nutritional status in children with un-operated congenital heart disease: an Egyptian center experience. Frontiers in Pediatrics, 3.

Ministry of Health, Republic of Indonesia, 2011. Keputusan Menteri Kesehatan Republik Indonesia nomor 1995 tahun 2010 tentang Standar Antropometri Penilaian Status Gizi Anak [Decree of the Minister of Health, Republic of Indonesia no. 1995 year 2010 on Anthropometric Standard of Child Nutritional Status Assessment].

Ministry of Health, Republic of Indonesia, 2013. Kamus [Dictionary]. Downloaded 25 October 2019 from https.//www.kemenkes.com.

Martins, I.F., Doles, I.C., Bravo-Valenzuela, N.J.M., dos Santos, A.O.R., Varella, M.S.P., 2018. When is the best time for corrective surgery in patients with Tetralogy of Fallot between 0 and 12 months of age? Brazilian Journal of Cardiovascular Surgery. 33(5): 505-10.

Marwali, E., Darmaputri, S., Somasetia, D., Sastroasmoro, S., Haas, N., Portman, M., 2015. Does malnutrition influence outcome in children undergoing congenital heart surgery in a developing country? Paediatrica Indonesiana, 55(3): 109-16.

Okoromah, C., Ekure, E., Lesi, F., Okunowo, W., Tijani, B., Okeiyi, J., 2011. Prevalence, profile and predictors of malnutrition in children with congenital heart defects: a case- control observational study. Archives of Disease in Childhood, 96(4): 354-60.

Ontoseno, T, Soebijanto., 2014. Buku ajar kardiologi anak penyakit jantung bawaan sianosis [Textbook of pediatric cardiology: congenital cyanotic heart disease]. Surabaya: Airlangga University Press.

Ruslie, R., Darmadi., 2013. Diagnosis dan tata laksana tetralogy of fallot. Academia. 40(3): 176-181.

Schwartz, S., Olsen, M., Woo, J., Madsen, N., 2017. Congenital heart disease and the prevalence of underweight and obesity from age 1 to 15 years: data on a nationwide sample of children. BMJ Paediatrics, 1: e000127.

Tchoumi, J.C.T., Ambassa, J.C., Giamberti, A., Cirri, S., Frigiola, A., Butera, G., 2011. Late surgical treatment of tetralogy of Fallot. Cardiovascular Journal of Africa, 22(4): 179-81.

Valente, A., Gauvreau, K., Assenza, G., Babu- Narayan, S., Schreier, J., Gatzoulis, M., Groenink, M., Inuzuka, R., Kilner, P., Koyak, Z., Landzberg, M., Mulder, B., Powell, A., Wald, R., Geva, T., 2014. Contemporary predictors of death and sustained ventricular tachycardia in patients with repaired tetralogy of Fallot enrolled in the INDICATOR cohort. BMJ Journal, 100(3).

Wulandari, A., Ontoseno, T., Umiastuti, P., 2018. Hubungan status gizi anak usia 2-5 tahun dengan kelainan jantung bawaan biru di RSUD Dr Soetomo Surabaya [Correlation between 2-5 y.o. children's nutritional status and blue congenital heart disease in Dr. Soetomo Hospital, Surabaya]. Sari Pediatri, 20(2).

Yasmin, A.D.A., Gunawijaya, E., 2015. A Child with Tetralogy of Fallot Presenting with Complication of Infective Endocarditis, Cerebral Abscess, and Undernutrition. Jurnal Ilmiah Kedokteran. 46(1): 3741. 